Izvirni znanstveni članek/Article (1.01)

Bogoslovni vestnik/Theological Quarterly 81 (2021) 1, 23-33

Besedilo prejeto/Received:10/2020; sprejeto/Accepted:03/2021

UDK/UDC: 274-28:929Luther M.

DOI: 10.34291/BV2021/01/Vodenko

(C) 2021 Vodenko et al., CC BY 4.0

Konstantin V. Vodenko, Yulia N. Sushkova, Nikolay N. Kosarenko, Olga V. Popova, Anton S. Skotnikov and Elmira R. Khairullina

\title{
The Reception of Aristotle in Martin Luther's Late Theological Writings
}

\section{Sprejemanje Aristotela v poznih teoloških delih Mar- tina Lutra}

Abstract: The ambiguous legacy of Martin Luther, the sixteenth-century German reformer, includes his expressive, intellectual reactions to Aristotle's ideas. His vehement criticism of the ancient philosopher in some of his later writings may have eclipsed Luther's more balanced reception of Aristotle in his early career. Furthermore, careful distinctions must be made between Luther's views on medieval Aristotelianism vs the original ideas of Aristotle. Finally, when assessing the German reformer's appraisal of Aristotle, it is vital to distinguish between the vertical, coram Deo, horizontal, coram hominibus, human situatedness, and interaction dimensions. This article argues that, despite the strong rejection of Aristotle's usefulness for theology by Luther, we can discern a limited use of Aristotelian categories by Luther when dealing with some matters of politics and ethics (the rule of law in a state and an individual's virtues). Based on Luther's mature writings, we will examine Luther's notions of sin, concupiscence, justification, divine grace, and human will, as these topics resonate in his treatment of Aristotle's philosophical heritage.

Keywords: Aristotle, Aristotelianism, Martin Luther, justification, reason, free will

Povz̧etek: Dvoumna zapuščina Martina Lutra, nemškega reformatorja iz 16. stoletja, vključuje njegove čustvene odzive na Aristotelove ideje. Zdi se, da je Lutrova ostra kritika antičnega filozofa v nekaterih njegovih poznih delih zameglila bolj uravnoteženo sprejemanje Aristotela v zgodnjih letih. Poleg tega je treba izpostaviti jasno razlikovanje med Lutrovim pogledom na srednjeveški aristotelizem in izvornimi Aristotelovimi idejami. Pri obravnavi vrednotenja, ki ga je 
o Aristotelu izražal nemški reformator, je nadalje ključno, razlikovati med vertikalno (coram Deo) in horizontalno (coram hominibus) razsežnostjo človeškega stanja in sporazumevanja. Članek zagovarja stališče, da je kljub izrazitemu zavračanju koristnosti Aristotela za teologijo pri Lutru mogoče opaziti omejeno rabo aristotelskih kategorij na področju političnih in etičnih zadev (vladavina prava v državi in kreposti pri posameznih osebah). Na podlagi Lutrovih zrelih spisov obravnavamo njegovo razumevanje greha, poželenja, opravičenja, božje milosti in človeške volje, saj prav te teme odmevajo skozi njegovo obravnavo Aristotelove filozofske dediščine.

Ključne besede: Aristotel, aristotelizem, Martin Luther, opravičenje, razum, svobodna volja

\section{Introduction}

Martin Luther is arguably one of the best-known and most controversial figures of the sixteenth century. Born at a time of late scholastics, in Europe torn amid warring factions (internal struggles) during the era of fascinating discoveries (the Americas) and inventions (such as the Gutenberg's printing press), and threatened by a potent outside enemy (the Ottoman Turks), the German reformer is hailed by many in the Protestant camp as a champion of the Christian Gospel, while cursed by others as the man who tore the seamless canvas of Western Christendom to pieces. His appeal to the primacy of divine revelation (revelatio specialis) as interpreted by the Church's tradition and perceived and internally digested by the individual believer's conscience, introduced a curious mix of mysticism (as seen, e.g., in his emphasis on the mystical union of Christ and the believer in faith; LW 31, 359), strict Augustinianism (as evidenced by his leaning toward Augustinian's doctrine of predestination and primacy of divine grace; LW 27, 255), and individual voluntarism into the theological discourse of his era. Luther's voluntaristic mysticism, as Jacques Maritain called it, "unbridled the human self in the spiritual and religious order, as the Renaissance /.../ unbridled the human self in the order of natural and sensible activities" (Maritain 1928, 8).

Among the numerous contentious points in Luther's theological legacy is undoubtedly his stance toward Aristotle or, more generally, philosophy as a path to spiritual wisdom. Already in Medieval times, intellectuals between the 1200 s to 1500s used surprisingly diverse ways to interpret competing currents of ancient and Christian moral thought to formulate a philosophical ethic fitting to their times (Bejczy 2008). The ever-increasing "emphasis upon dialectic as a primary instrument of formal inquiry was augmented in the mid-12th century by the recovery of critical works on logic by Aristotle« (Luy 2017). These attempts, naturally, continued after Luther through to the birth of the modern era, which further testifies to their theological significance. For example, attempts were made to establish a clear line from Aristotle through St. Thomas Aquinas to modern, democratic po- 
litical thought (Jefferson, Truman, etc.) to substantiate the existence of ,western political philosophy' (Jaffa 1952).

However, not all in and outside the Church viewed Aristotle's ideas with sympathy. Luther's nominalist training in philosophy seemed to predispose him to question rational, intellectual explanations (Schwarz 1962) and assume a profound anti-intellectual approach. Thus, when speaking of Aristotle and St. Thomas, he allegedly said: "Aristotle is the godless bulwark of the papists. He is to theology what darkness is to light. His ethics is the worst enemy of grace." (Maritain 1928, 15) Among his derogatory comments targeted at Aristotle were many ad hominem attacks and hyperbolic ridicule against the Greek philosopher. Luther writes that Aristotle is "an urchin who must be put in the pigsty or donkey's stable " (WA VII, 282, 15-16) and that he is a mediocre philosopher (IX, 43, 5) who should be rejected by faithful Christians (I, 647, 33-34). On the other hand, Luther had good things to say about Aristotle, too, recommending his writings on methodology and ethics and even stating explicitly that, at least on some topics, "Aristotle philosophizes about such matters, and he does it well« (LW 25, 434).

However, what made things complicated was that "people do not understand him well, " as Luther complained (434). Luther often complained that both the scholastic teachers before him and many of his contemporaries had misunderstood Aristotle's thinking (Eckermann 1978). St. Thomas Aquinas, according to the German reformer, belonged among those who "never understood a chapter of the Gospel or Aristotle" (Maritain 1928, 15). If this observation carries any weight, Luther's criticism of Aristotle could be partially interpreted as his opposition to the typical scholastic intellectual rendering of Aristotle's ideas rather than to Aristotle himself (Nitzsch 1883; Oberman 1966). Luther became familiar with Aristotle by collecting the writings translated into Latin and became accessible to him in his Erfurt city school (1502-1505). He also read commentaries on Aristotle's works by renowned medieval teachers - Peter Lombard, Duns Scotus, Pierre d'Ailly, Gabriel Biel, etc. (Dieter 2015).

In our research, we will primarily focus on Luther's later, more mature writings. These include (1) Luther's commentaries - Commentary on the prophetic books Zachariah and Isaiah; Commentary on Ecclesiastes; Commentary on Galatians; (2) Luther's scholastic disputations - Concerning Man (Disputatio de homine, 1536) (WA 39, I, 175-177); Concerning Justification; Concerning Christ's divinity and humanity; and (3) Luther's lectures given during his late Wittenberg university teaching career - Lectures on Titus, 1 Peter and 1 John. This source material will provide us with concrete examples of Luther's views on important theological topics, including justification, grace, the natures of Christ, and free will, and the nature of sin and concupiscence. Rather than providing a detailed description and critical analysis of these topics from Luther's perspective, our goal will be to examine Luther's treatment of Aristotle's ideas and his influence on Luther's contemporaries (from Luther's limited perspective) relative to the selected theological issues. 


\section{Luther's commentaries: Zachariah, Isaiah, Ecclesiastes}

Luther wrote his commentaries on Zachariah, Isaiah, and Ecclesiastes between 1527-1532. They all belong among his more mature writings. His relationship with Aristotle is ambivalent, as one can witness by reading Luther's early works (Dieter 2015; Brecht 2009). His positive comments usually relate to the philosopher's ideas about the matters of the state (namely, the rule of law in the state) and civic morality (WA 20, 120, 19-20). This can further be evidenced by Luther's exposition of Luke 2:15-20 contained in his Collection of Sermons (Kirchenpostille, 1522):

»Thus in our active life, we are to stick with the needy, while in our studies and in our contemplative life we are to stay only with God's word so that Christ alone is in both respects the man who is everywhere before us. The books of Aristotle and those of the pope and of any other man should be avoided, or they should be read in such a way that we do not seek in them information concerning the edification of the soul, but we should use them to improve our temporal life, to learn a trade or civil law." (LW 52, 39)

It is here, in the earthly realm or, as Luther puts it, coram hominibus, where reason and unredeemed conscience play an important role. We can trace this idea in Luther's other commentary, on the Book of Revelation 3:20, where he argues that "no one is so evil that he does not feel the murmur of reason and the voice of conscience, according to the statement, sreason always speaks for the best.l And this explanation is indeed very attractive." (LW 10, 99; Aristotle, Nicomachean Ethics I, 1102b, 15) Elsewhere in his texts, Luther admits that humans did not lose rationality after the Fall: "After the fall of Adam, God did not take away this majesty of reason, but rather confirmed it." (LW 34, 137; Janz 2011, 48) Commenting on Ecclesiastes 1:7, Luther openly acknowledges Aristotle's scientific observations regarding the origin of the ,springs' and ,winds', while lifting Solomon's wisdom as superior to the wisdom of the philosophers: "Aristotle disputes about where springs and winds come from and sweats over this investigation, as do many others. However, nowhere do we find what Solomon says here, that all streams come from the sea and in turn fill the sea." (LW 15, 16-17)

Passages with a more critical flavour can be found more abundantly, however. In the preface to his Lecture on Zachariah $(20,156)$, Luther points out, somewhat sarcastically, that Aristotle is not of much use to people who lack proper education because his writing style is too complicated. The polemical tone increases as soon as Luther engages more theologically essential topics, such as the nature of the human soul. He vehemently rejects Aristotle's teaching about the mortality of the soul.

"The world, of course, cannot understand or believe that the soul is immortal. In fact, if you look at how things go and at the appearance about which Solomon is speaking when he says, >Man dies as the beast does, 1 they do have the same breath as the beast. In appearance, therefore, we coincide. The philosophers have indeed disputed about the immortality of the soul, 
but so coldly that they seem to be setting forth mere fables. Aristotle above all argues about the soul in such a way that he diligently and shrewdly avoids discussing its immortality anywhere; nor did he want to express what he thought about it.« (15, 59; Aristotle, De anima I, 1; Sorabji 1974, 63-65)

Even a harsher tone comes across to readers from Luther's Commentary on Isaiah (based on his lectures from 1527-1530). The German reformer appears to be incredibly unforgiving when dealing with the topics of the sacraments and the human will. Luther argues that when the faithful forsake the simple, biblical teaching of Christ, they are led astray by the sophistries of the philosophers.

»Once we have forsaken Christ, all monsters, beasts, and demons lead us astray; error follows upon error. This we see today, first concerning Baptism, then concerning the Eucharist, then concerning free will so that one error follows hard upon the other. As one wild beast falls in with another, so it was hitherto under the papacy. Aristotle, Scotus, etc., fell in with each other. « (LW 16, 297)

Complaining about the perceived unfaithfulness of many of his contemporaries, including monks and scholastic teachers, Luther laments in the second volume of his Commentary on Isaiah 42:7 that Christ »is despised by so many monasteries and schools that it is impressive. We ignore Him and read the monstrous material of Aristotle. « $(17,69)$ The immediate reference here is to the doctrine of free will which Luther utterly despised. He is adamant that vapart from Christ there is nothing but darkness and dungeon. Away with free will!«, exclaims Luther emphatically, for »it is not enough to shine. One must also see and act. Nor is it enough to burn. Thus here, too, all lights apart from Christ are darkness, as is free will. Afterwards there is also captivity. Even though we see the Gospel, we cannot perform it, and there is nothing but prison. " (69) If philosophical reason ever attempts to understand what God is like or offer guidance in the human quest for salvation, Luther further argues, it will inevitably lead us to error (Janz 2011, 49), as evidenced by Erasmus' foolish insistence on the freedom of the will coram Deo inspired by humanism and Aristotle (WA 10, I, 532, 1-12).

\section{Luther's scholastic disputations: concerning man, concerning justification, concerning the divinity and humanity of Christ}

Luther took part in scores of scholastic disputations from as early on as 1516. Among these, the disputations Concerning Man (1536; WA 39, I, 174-180; LW 34), Concerning Justification (1536; WA 39, I, 78-126; LW 34), and Concerning the divinity and humanity of Christ (1540; WA 39, II, 92-121) contribute to an important theological legacy of the reformer. They also happen to be revealing when it comes to assessing Luther's relationship to Aristotle. All three disputations bear the same fundamental 
testimony: when choosing one's epistemological starting point, Luther (representing revealed theology) and Aristotle (representing philosophy, i.e., human wisdom based on revelatio naturalis) stand on the opposite sides. However, Luther freely employs Aristotle's linguistic/semantic and logical tools and categories to prop up his theological arguments, and he is even willing to acknowledge it by citing Aristotle's name. For example, to defend a proper distinction between the concrete sense of the term ,human' as opposed to the general sense of the term , humanity', Luther appeals to Aristotle's differentiation between nature (general) and person (concrete): "Aristoteles dicit: Abstracta sonant naturam, concreta personam [abstract terms refer to nature, the concrete ones to a person] « (108; 116-117).

While fitting examples of Luther's fair use of Aristotle are scarce, his criticism of the philosopher finds ample expressions. Defending his hermeneutical understanding informed by his presupposition of the literal theological meaning of vital biblical accounts (i.e., those directly related to salvation history), Luther argues that Christ's humanity and divinity must be understood as having been manifested in a concrete historical person: „Christ is not a mathematical or physical word but a divine, uncreated Word, who signifies the essence as well as the person because God's Word is divine. Christ is God's Word. Thus, Christ is divine. Philosophically, a word stands for a sound or an utterance, but when we speak theologically, Word signifies the Son of God [Verbum significat filium Dei]. Aristotle would never allow this, that is, that a word should signify the true God." (WA 39, II, 103, 11) We find a similar reservation in two more places of the disputation when Luther argues that »Aristotle would not agree with this" $(112,19)$ and »Aristotle would not be able to understand this matter « $(118,27)$.

The same type of ,limitation' on the side of the philosophical reason as represented by Aristotle can be found in several places of Luther's Disputation concerning Justification. Instead of focusing on the inner life of the Trinity or the essence and characteristics of the three divine persons, the topic here revolves around some critical issues of theological anthropology and hamartiology. The main line of reasoning consists of Luther's insistence on scholastic theology being permeated with (and therefore limited by) Aristotelian presuppositions, which steers it away from traditional,gospel-oriented biblical theology. While scholastic theology, in Luther's view, perceives the human condition more optimistically, biblical revelation paints a much more pessimistic picture that brings us (theologizing humans) down from the clouds of our arrogant reasoning to the grim reality of sin. Luther argues against the scholastic insistence on man being merely weak, which makes one prone to sin, but which in and of itself is not harmful.

»But the scholastic doctors contend that it is only a condition and not sin of the kind that would cast us away from the eyes of God. Just as Aristotle speaks of affections which are in us but bring us neither blame nor praise, so according to them as according to him, concupiscence is a kind of indifferent affection, or, as they call it, ,adiaphoron', which does not damn us, and which is neither advantageous nor injurious to us." (LW 34, 186) 
We find here an explicit reference to Aristotle's Nicomachean Ethics, in which Aristotle argues that "we are not called good or bad on the ground of our passions" (Aristotle, Nicomachean Ethics II, 4; Polansky 2014, 4). Concupiscentia, according to Luther, is far more than an inclination toward sin; it is a Sin itself. It is the very essence of human sinfulness (WA 39, I, 118, 1-7).

»For original sin is not only the lack of righteousness, but a kind of inborn evil, as said before, which makes us guilty of sin and eternal death, subject to divine wrath. It remains in us even after baptism and resists the law of God and the Holy Spirit. These are the sound distinctions of this definition, which the papists did not understand at all. Therefore, they did not define original sin correctly. For anyone who has not truly learned all aspects of this definition of original sin does not know sin.« (LW 34, 186)

Original sin, Luther opines, is »a kind of corruption of nature, which drives us to resist the Spirit « $(34,186)$. In place of Aristotle, whose misleading role had Luther just exposed, Christians should place their faith in St. Augustine and St. Paul (above all his letters to Romans and Galatians).

"Accordingly, since that very concupiscence is really that evil which is innate in us by nature and which even in the righteous struggles against the law of God and finally lasts until the grave, it is necessary for us to examine original sin diligently, to see what it is. Augustine, who is one of the preservers of the definition of original sin, truly acknowledged this. « $(34,186-187)$

Luther blames Aristotle for not being honest enough to himself, i.e., failing to see the true depravity of his sinful nature. "/f Aristotle had understood the innate sinful condition, he would have called it a disposition [habitum], not only an affection [passionem].« $(34,165)$

Luther's conviction about the necessity of distinguishing and separating the theological from the philosophical reasonings is best evidenced in his Disputation concerning Man. Commenting on the failure of philosophy to properly understand the essence of sin and its effect on human nature, Luther says: "Therefore those who say that natural things have remained untainted after the fall philosophize impiously in opposition to theology." (Thesis 26; LW 34, 139) This is also true "of those who introduce Aristotle (who knows nothing of theological man) to witness that reason aspires to the best things (Thesis 28; LW 34, 139). According to Luther, Aristotle, along with his contemporaries - the philosophizing scholastic theologians - know nothing about a man (Thesis 31; LW 34, 139) because they speak from without the biblical tradition as mundane, carnal men. To avoid their mistakes, Luther argues, theologians must approach these issues from within as ,theological men'. Hence Luther's conclusion that a genuine theologian must clearly distinguish between philosophy and theology and refrain from using fundamental philosophical presuppositions about man, God, sin, grace, the free will (and alike) in one's theological treatment of these topics. This, according to Luther, is precisely where Aristotle fails the most. 
"Therefore, if philosophy or reason itself is compared with theology, it will appear that we know almost nothing about man, inasmuch as we seem scarce to perceive his material cause sufficiently. For philosophy does not know the efficient cause for certain, nor likewise, the final cause, because it posits no other final cause than the peace of this life and does not know that the efficient cause is God the creator. Indeed, concerning the formal cause which they call soul, there is not and never will be agreement among the philosophers. For so far as Aristotle defines it as the first driving force of the body which has the power to live, he too wished to deceive readers and hearers. " (Theses 11-16; LW 34, 137-138)

\section{Luther's lectures in Wittenberg: lectures on Titus, 1 Peter, and 1 John}

Luther lectured on these biblical books sometime between 1525-1527. In his lectures, we find clear passages commending the ideas of Aristotle. Among them is Luther's exposition on Titus 3 where Luther invokes Aristotle's definition of the

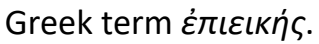

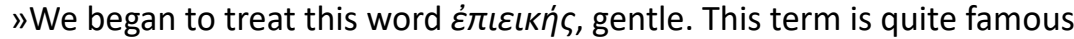
among the Greeks but not so famous among the Latins. /.../ Jurists define it as equity when on account of an intervening case, they soften the rigour of the law. Aristotle says in the fifth book of his Ethics (Nicomachean Ethics $\mathrm{V}, 10$ ) that when a legislator sets down a law, he makes a distinction: The law is impossible because moral questions concern themselves with the person. « (LW 29, 74-75)

Luther prefers Aristotle's explanation to that of the sjuristsı who preferred to translate the term with the Latin word aequitatem. Likewise, in a lecture delivered on Titus 1 in November 1527, Luther observed that St. Paul had quoted a heathen poet in Tit 1:12. "That verse is true, even though it was written by a heathen poet. These are spoils which we can take away from them. But it requires art to apply these things to spiritual matters. Plato and Aristotle wrote well about political matters, Pliny described the works [of nature], etc. "But he is quick to add that Christians should "not undertake to have a heathen instruct conscience. Only Christ, our Teacher, is competent for this. « $(29,39-40)$

In most other instances, however, Luther's apocalyptic reading of the Scriptures comes to the forefront, as we saw in his commentaries and other types of literature. He views the world as the arena of a raging war between the Devil's forces and the divine forces under the leadership of the risen Christ. Aristotle is often depicted as a tool in Satan's hands to lead the people of God astray. We can see this in Luther's comments on the text from 1 Pt 3,15. The reformer maintains that all Christians are to be prepared to make a defence of their faith, account for the hope in them, and only achieve this through a careful study of Scriptures. 
"Now up to this time, the laity has been forbidden to read Scripture. For here, the Devil came up with a pretty trick for the purpose of tearing the people away from Scripture. He thought: IIf I can keep the laity from reading Scripture, then I shall bring the priests from the Bible into Aristotle. Then the priests can babble what they please, and the laity has to listen to what they preach to them.« $(30,105)$

Aristotle is elevated above the Scripture, according to Luther, with the pretence that the philosopher's teaching is more apt "to overthrow heretics $(30,107)$. Such a view is misleading and dangerous to the simple minds of Christians and the teachers of the Church, who should find solace and inspiration in the Bible instead.

\section{Conclusion}

As his theological views matured through his study of the Scriptures and the Tradition, Luther grew ever more convinced that to reform the Church, philosophy (above all the Aristotelian metaphysics) must be excluded, along with Scholastic theology and Canon Law. He even suggested that those holding the view that if something is true for philosophy must necessarily be true for theology, they should be condemned. Hence his emphatic denunciation of the theologians at the Sorbonne University, which he labelled ,the mother of all errors', ,the most abominable prostitute', and ,the damned synagogue of the devil' (Zahnd 2018, 460). Moreover, hence his rage oriented toward "the most famous Aristotle, that noble light of nature, that heathen master, that arch master of all masters of nature, who rules in all of our universities and teaches in place of Christ« (LW 52, 165).

While we can see some development in his treatment of Aristotle's ideas during the turbulent decades of Luther's polemics, disputations, and writings, his basic stance did not change much. We can observe this in the last sermon he preached at Wittenberg, towards the end of his life, as Maritain rightly points out in his criticism of the reformer:

»Reason is the Devil's greatest whore; by nature and manner of being she is a noxious whore; she is a prostitute, the Devil's appointed whore; whore eaten by scab and leprosy who ought to be trodden under foot and destroyed, she and her wisdom... Throw dung in her face to make her ugly. She is, and she ought to be, drowned in baptism... She would deserve, the wretch, to be banished to the filthiest place in the house, to the closets." (ERL 16, 142-148; Maritain 1928, 16)

Reason can only dishonour and blaspheme God and everything He has made (LW 51, 374). Thus, we may ask: Is Luther's dramatic denunciation of the power of reason viable as a constitutive principle in healthy theology? Is it based on a correct understanding of theological anthropology, or does it instead stem from 
Luther's over-derogatory conception of human nature, plagued by original sin? Luther's contempt for the power of reason is understandable if it can be established that human nature is, indeed, severely afflicted by the original, rendering the human agent incapable of adequately responding to God when left to his/her powers. If Luther's unfounded presuppositions were true, then the use of Aristotle in particular and human reason, in general, would be illegitimate in uncovering, comprehending, and adopting the mysteries of the Christian faith (the realm of theology). It would then be true that "reason is contrary to faith « $(E R L 44,158)$ and that "reason is directly opposed to faith, and one ought to let it be; in believers, it should be killed and buried « (ERL 44, 156-157; Maritain 1928, 16).

However, such a negative perception of human nature is unfounded and relatively scarce in the ecumenical tradition of the Church (even more so in the Eastern Tradition than in the West). One would need to go all the way to Augustine to identify the roots of this doctrine, later developed in the form of,strict Augustinianism' of John Calvin and his supporters (Bayer 2008; Schwarz 1962). Revealingly, Luther himself was an Augustinian monk, partially explaining his affinity to this strand of theology (Wriedt 2011). Furthermore, owing to his existential struggle and, perhaps, his tragic and melancholic character, Luther seemed to have preferred the mysticism of inner faith to employ philosophical reason to solve questions about faith or those growing out of one's fundamental spiritual outlook. On the other hand, Luther was willing to concede that philosophical reasoning has had a practical value for daily use in earthly life. After all, he used Aristotle's categories of logic and claimed that some of the philosopher's ideas were useful when dealing with the mundane realm, coram hominibus. In addition to logic, he considered poetics, rhetoric, and semantics beneficial to theologians and all who strived for a good education. However, in the spiritual sphere, it allegedly only shed darkness, which contrasts to a great majority of the Western Christian intellectual tradition and even more so to Russian Orthodox theological thinking (Obolevitch 2015; Khoruzhy 2015; Allen et al. 2016). This feature of Luther's theology, among other problems, may have been the reason why his thinking never made any significant inroads into the Russian cultural-religious landscape. To delve deeper into this issue, however, a separate study will need to be conducted.

\section{Abbreviations}

ERL - Luther 1826-1857 [Dr. Martin Luther's sämmtliche Werke].

LW - Luther 1955-1986 [Luther's Works].

WA - Luther 1883-2009 [D. Martin Luthers Werke: Kritische Gesamtausgabe]. 


\section{References}

Allen, Artur Mrówczyński-Van, Obolevitch, Teresa, and Rojek Paweł, eds. 2016. Beyond modernity: Russian Religious Philosophy and Post-Secularism. Eugene, OR: Pickwick Publications.

Aristotle. 2000. Nicomachean Ethics. Cambridge Texts in the History of Philosophy. Translated and edited by Roger Crisp. Cambridge: Cambridge University Press.

- - - 2016. De anima. Translated by Christopher Shields. Oxford: Clarendon Press.

Bayer, Oswald. 2008. Martin Luther's Theology: A Contemporary Interpretation. Grand Rapids: William Eerdmans Publishing.

Bejczy, István, ed. 2008. Virtue Ethics in the Middle Ages: Commentaries on Aristotle's Nicomachean Ethics, 1200-1500. Leiden; Boston: Brill.

Brecht, Martin. 2009. Martin Luther: Shaping and Defending the Reformation 1521-1532. Vol. 2. Minneapolis: Fortress Press.

Dieter, Theodor. 2015. Der junge Luther und Aristoteles: eine historisch-systematische Untersuchung zum Verhältnis von Theologie und Philosophie. Berlin; New York: Walter de Gruyter.

Eckermann, Willigis. 1978. Die Aristoteleskritik Luthers: Ihre Bedeutung für seine Theologie. Catholica Münster 32, no. 2:114-130.

Jaffa, Harry V. 1952. Thomism and Aristotelianism: A Study of the Commentary by Thomas Aquinas on the Nicomachean Ethics. Chicago: University of Chicago Press.

Janz, Denis R. 2011. Whore or Handmaid? Luther and Aquinas on the Function of Reason in Theology. In: Jennifer Hockenbery Dragseth, ed. The Devil's Whore: Reason and Philosophy in the Lutheran Tradition, 47-52. Minneapolis: Augsburg Fortress Publishers,

Khoruzhy, Sergei. 2015. Eastern-Christian Discourse and Russian Philosophy: Basic Structures, Modern Problems. In: Teresa Obolevitch and Pawel Rojek, eds. Faith and Reason in Russian Thought, 25-40. Krakow: Copernicus Center Press.
Luther, Martin. 1955-1986. Luther's Works. Edited by Jaroslav Pelikan. Philadelphia: Fortress Press.

- - . 1883-2009. D. Martin Luthers Werke. Kritische Gesamtausgabe. 121 vols. Weimar: Hermann Böhlau.

- - . 1826-1857. Dr. Martin Luther's sämmtliche Werke. Erlangen-Frankfurter Ausgabe. 134 vols. Erlangen: Heyder.

Luy, David. 2017. Martin Luther's Disputations. In: Oxford Research Encyclopedia of Religion. https://oxfordre.com/religion/view/10.1093/ acrefore/9780199340378.001.0001/acrefore-9780199340378-e-285. DOI: 10.1093/ acrefore/9780199340378.013.285. (accessed 10. 10. 2020).

Maritain, Jacques. 1928. Three Reformers: Luther, Descartes, Rousseau. London: Sheed \& Ward.

Nitzsch, Friedrich A. 1883. Luther und Aristoteles: Zu haben in der Universitäts-Buchhandlung. Kiel: Universitäts-Buchhandlung.

Oberman, Heiko. 1966. Forerunners of the Reformation: The Shape of Late Medieval Thought. New York: Lutterworth Press.

Obolevitch, Teresa. 2015. Faith as the Locus Philosophicus of Russian Thought. In: Teresa Obolevitch and Pawel Rojek, eds. Faith and Reason in Russian Thought, 7-23. Krakow: Copernicus Center Press.

Polansky, Ronald, ed. 2014. The Cambridge Companion to Aristotle's Nicomachean ethics. Cambridge: Cambridge University Press.

Schwarz, Reinhard. 1962. Fides, spes und caritas beim jungen Luther. Berlin: Walter de Gruyter.

Sorabji, Richard. 1974. Body and soul in Aristotle. Philosophy 49, no. 187:63-89.

Wriedt, Markus. 2011. Luther and Augustine - Revisited. In: Jennifer Hockenbery Dragseth, ed. The Devil's Whore: Reason and Philosophy in the Lutheran Tradition, 39-46. Minneapolis: Augsburg Fortress Publishers. 